Dział: Ogrodnictwo i Architektura Krajobrazu

DOI: http://dx.doi.org/10.17306/J.NPT.2016.4.50

Copyright @Wydawnictwo Uniwersytetu Przyrodniczego w Poznaniu

BEATA FORTUNA-ANTOSZKIEWICZ, JAN ŁUKASZKIEWICZ

Department of Landscape Architecture

Warsaw University of Life Sciences - SGGW

\title{
GENESIS AND CHARACTERISTICS OF WOODLOT FORMS IN THE LANDSCAPE OF SOUTHERN ENGLAND
}

\author{
GENEZA I CHARAKTERYSTYKA FORM ZADRZEWIEŃ \\ W KRAJOBRAZIE POŁUDNIOWEJ ANGLII
}

\begin{abstract}
Summary
Background. The paper is a synthesis of the research on the genesis and characteristics of woodlot forms in the traditional English landscape. Historically, their origin is related among other things to the British being inspired by the Arcadian myths popular in the $16^{\text {th }}$ and $17^{\text {th }}$ centuries, as a result of trips to places like Italy or the Far East, and a fascination with nature. At the same time the $16^{\text {th }}$ century was characterized by a progressive and gradual deforestation of the landscape of the island. Therefore, during the $17^{\text {th }}$ and $18^{\text {th }}$ centuries a very particular cultural landscape of England developed, of which the specific pastoral physiognomy found some representation in the archetype of the $19^{\text {th }}$-century English park. This can be clearly stated on the example of woodlots, which very similar forms can be shown both in English agricultural landscape and in English parks. The aim of this research was to analyse forms and functions of selected examples of woodlots in southern England.

Material and methods. The collection of field data took place in April 2015 during scientific workshops organized by the Polish Dendrology Society (PTD), devoted to woody plants of southern England (including Surrey and vicinity). As a result, the physiognomy of the complex system of woodlots was analysed in situ and a rich photo documentation was collected.

Results and conclusions. It can be stated that the forms of woodlots occurring in the contemporary English landscape bear a strong resemblance to those presented in $19^{\text {th }}$-century landscape paintings. This is a phenomenon of effective protection of the physiognomy of the cultural landscape, which has survived virtually unchanged after more than two centuries. As a result, the authors characterized exceptional values of woodlots to traditional rural and parkland landscape in southern England as an example for development and protection of the cultural landscapes in Poland - both in the past and the present.
\end{abstract}

Key words: woodlot forms, parks and landscape of southern England, landscape protection 
Fortuna-Antoszkiewicz, B., Łukaszkiewicz, J. (2016). Genesis and characteristics of woodlot forms in the landscape of southern England. Nauka Przyr. Technol., 10, 4, \#50. DOI: http://dx.doi.org/10.17306/J.NPT.2016.4.50

\section{Introduction}

Comparing the contemporary English cultural landscape with the one recorded by the landscape painting over 200 years ago, it is easily noticeable that woodlots have always been its indispensable part. The aim of the study was a general characteristics of woodlots occurring both in parks and agricultural landscape of southern England - their forms and functions. Revealing the exceptional significance and values of the English woodlots may presently - same as 200 years ago - be an example both for the development and protection of the Polish cultural landscape.

\section{Material and methods}

According to the intended objective, the study was divided into three stages. Firstly, the genesis of woodlots in the English landscape was presented, relating to the conditions, i.e. cultural, natural and economic that initiated this phenomenon. Following, the contemporary formal and legal conditioning, in force in GB, applied to preserve and protect cultural and natural values of the country's landscape (including woodlots), was identified. It was done in the context of: the state's policy, forms of trees protection, subsidies for agriculture - as an instrument of the maintenance of midfields woodlots located in agricultural landscape, as well as forests - and procedures of trees removal (felling) from agricultural areas. The data gathered by the authors originate both from theoretical materials and own professional scientific and practical experiences.

The first two stages used the method of literature and iconography sources content analysis. The third section of the work contains synthetically presented results of field observations carried out during scientific workshops organized by the Polish Dendrology Society (PTD) (April 2015) and devoted to woody plants of southern England (e.g. Surrey county and its vicinity).

The authors analysed in situ the physiognomy of the complex mid-grasslands woodlots system, identified the forms of the woodlots, and gathered a rich photo documentation. The completion of the work are a general summary and conclusions, which may constitute a reference for the development of woodlots in the landscape of Poland, both presently and in the future.

\section{Genesis of woodlots in the landscape of England}

The forms of woodlots characteristic for the landscape physiognomy of southern England were formed as a result of a coincidence of a few crucial factors; the most important ones are:

- inspiration of the English by the Arcadian myth present in the philosophy, poetry and painting of $16^{\text {th }}$ and $17^{\text {th }}$ centuries, where the landscape was freely stylized ${ }^{1}$,

\footnotetext{
${ }^{1}$ E.g. Altdorfer (Germany, $16^{\text {th }}$ c.), Rubens, Rembrandt (Netherlands, $17^{\text {th }}$ c.), Salvator Rosa, Magnasco (Italy, $17^{\text {th }}$ and $18^{\text {th }} \mathrm{c}$.).
} 
Fortuna-Antoszkiewicz, B., Łukaszkiewicz, J. (2016). Genesis and characteristics of woodlot forms in the landscape of southern England. Nauka Przyr. Technol., 10, 4, \#50. DOI: http://dx.doi.org/10.17306/J.NPT.2016.4.50

or served as "theatre coulisses" (background) for the action presented on paintings $^{2}$ (Majdecki, 1981; Siewniak and Mitkowska, 1998);

- travels of islanders to southern Europe - especially to Italy ${ }^{3}$ - as well as their trade contacts with the Far East, and especially China, including the close-to-nature Chinese garden art (Majdecki, 1981, 1993b; Siewniak and Mitkowska, 1998);

- formation of society's particular philosophical attitudes of nature perception already in the $16^{\text {th }}$ and $17^{\text {th }}$ centuries (works of philosophers and poets of the period, e.g. Bacon, Milton, Addison, Shaftesbury, Pope), which brought about a visible surfeit with baroque and classicism and a negation of regular gardens on the turn of the $17^{\text {th }} / 18^{\text {th }}$ centuries $^{4}$, and turn of preferences towards natural landscape ${ }^{5}$ (Majdecki, 1981; Siewniak and Mitkowska, 1998);

- degradation of the native landscape of England - the $16^{\text {th }}$ and $17^{\text {th }}$ centuries faced the process of close-to-total deforestation (Siewniak and Mitkowska, 1998); the process resulted, first of all, from the wasteful management at that time, aiming at satisfying the needs of people for fuel and the shipbuilding industry which faced a strong competition for England's dominance at sea.

As a result of the above-mentioned events England became the birthplace of the $18^{\text {th }}$ -century social-philosophical and artistic movement, which aimed at ornamenting the landscape employing naturalistic forms of woodlots ${ }^{6}$. They showed a meaningful resemblance to those used in landscape parks and expressed in the form of: soliters, espaliers and hedges, groups, clusters, clumps, thickets, groves and forest massifs ${ }^{7}$ (Fortuna-Antoszkiewicz, 2012; Majdecki, 1981, 1993b; Mayer, 2014; Siewniak, 1990; Siewniak

${ }^{2}$ E.g. Titian and Carracci brothers (Italy, $16^{\text {th }}$ and $17^{\text {th }}$ c.), Poussin and Claude Lorrain (France, $17^{\text {th }} \mathrm{c}$.).

${ }^{3}$ The visited gardens e.g. ancient gardens of Neron in Rome, and Hadrian's Villa in Tivoli, late Middle Ages Italian landscape gardens and Calvary parks, Quatrocento and Cinquecento manieristic gardens, as well as Italian ones built in the Arcadian spirit of the turn of $16^{\text {th }} / 17^{\text {th }}$ centuries (Villa Montalto gardens in Rome, 1590 - arch. Domenico Fontana; Trinita dei Monti in Rome, 1661 - arch. Giovanni Lorenzo Bernini).

${ }^{4}$ The main promoters of the rejection of the old canons of garden art were e.g.: Joseph Addison (1672-1719), John Locke (1632-1704), Stephen Switzer (1682-1745) and Batty Langley (1696-1751).

${ }^{5}$ Similar ideas also appeared in Europe; Jean-Jacques Rousseau, a famous French philosopher, was an advocate of return to nature.

${ }^{6}$ The renewed afforestation of the English landscape is attributed e.g. to such people as John Evelyn (1620-1706) - a well-known writer and diarist of the times, and a gardener at the same time. His appeals concerning introduction of trees on deforested areas of England were supported by sound arguments both of patriotic and economic nature. First of all, many-kilometers avenues were established (end of $17^{\text {th }}$ c.) (e.g. horse-chestnut, beech, elm) situated on the rims of vast area estates. Owners of medium and small size estates and lands joined the process of the country's afforestation, along with land leaseholders, in the $18^{\text {th }}$ century, planting trees and establishing double rows and hedges along balks and fields (Majdecki, 1981, 1993b; Siewniak and Mitkowska, 1998).

${ }^{7}$ Attempts in the field were undertaken by pioneers and creators of the English-landscape style, parallel developing in the garden-art, e.g.: Kent, Capability Brown, Repton, Whately (Mayer, 2014). 


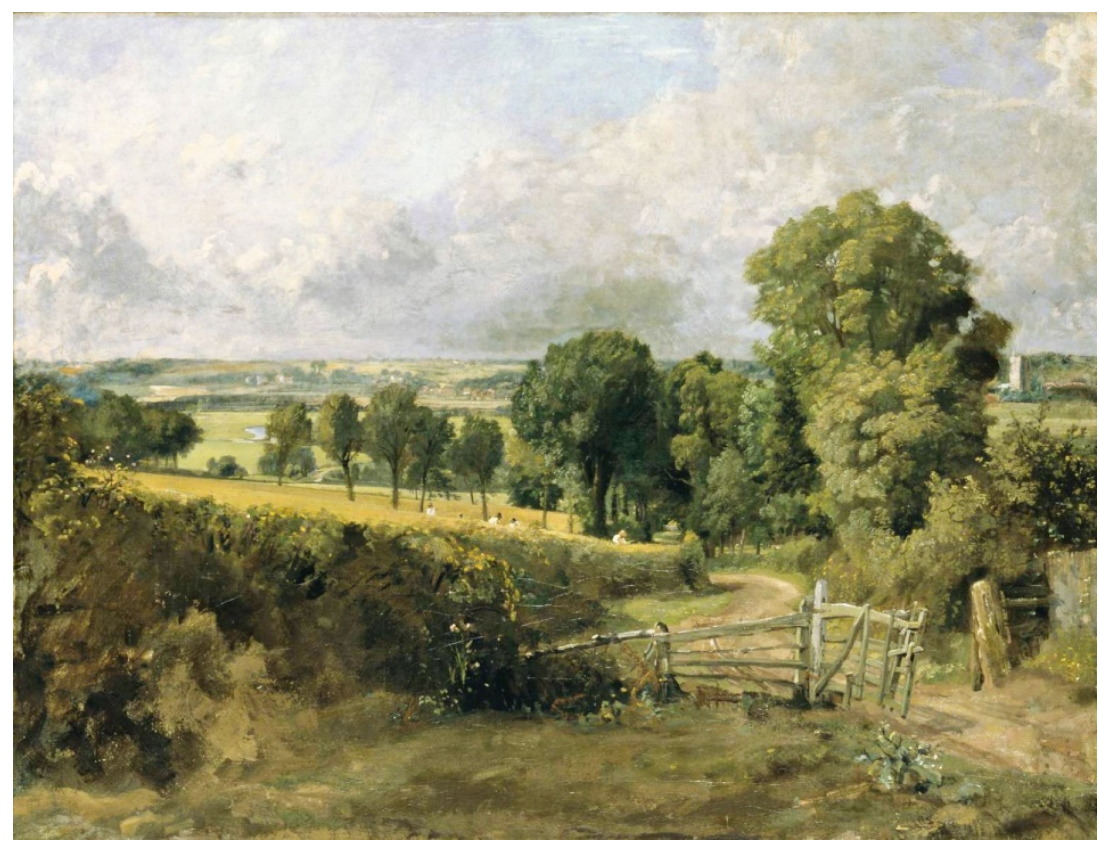

Fig. 1. England's $19^{\text {th }}$-century landscape, Suffolk - "Fen Lane, East Bergholt", author: John Constable, approx. 1817 (Tate Gallery, http://www.tate.org.uk/art/artworks/cons table-fenlane-east-bergholt-t07822)

Rys. 1. Pejzaż XIX-wiecznej Anglii, hrabstwo Suffolk - „Błotnista droga, East Bergholt”, autor: John Constable, ok. 1817 (Tate Gallery, http://www.tate.org.uk/art/art works/constable-fenlane-east-bergholt-t07822)

and Mitkowska, 1998; Toomer, 2010) (Fig. 1). The naturalistic parks established in England, owing to the above reasons, were smoothly integrated with the neighbouring landscape which simultaneously would penetrate into their interiors (Fig. 2).

Introduction of woodlots aiming at ornamenting the landscape around parks was imitated afterwards $\left(19^{\text {th }}\right.$ c.) in other European countries, e.g.: Ermenonville in France, Wörlitz and Muskau in Germany, or Łańcut and Zarzecze in Poland (Majdecki, 1981, 1993b; Siewniak and Mitkowska, 1998). Later, a broader idea of "park landscape", spreading over successive parks and farms, appeared in England ${ }^{8}$. Alike, the trend was followed then, to a various extent, in other European countries, e.g.: Sanssouci, Klein-Glienicke parks (Germany), the vicinity of Wilanów in Warsaw, reaching the branch gardens in Gucin Gaj, Ursynów and Natolin (Majdecki, 1981, 1993a; Siewniak and Mitkowska, 1998).

\footnotetext{
${ }^{8}$ Expression of this tendency became the utopian concept emerging from the Arcadian idea of transforming the whole of England into a garden in „The Leasowes” park fashion. Imitating the object, made popular by William Shenstone, a poet (1714-1763), numerous ornamental farms were established.
} 
Fortuna-Antoszkiewicz, B., Łukaszkiewicz, J. (2016). Genesis and characteristics of woodlot forms in the landscape of southern England. Nauka Przyr. Technol., 10, 4, \#50. DOI: http://dx.doi.org/10.17306/J.NPT.2016.4.50

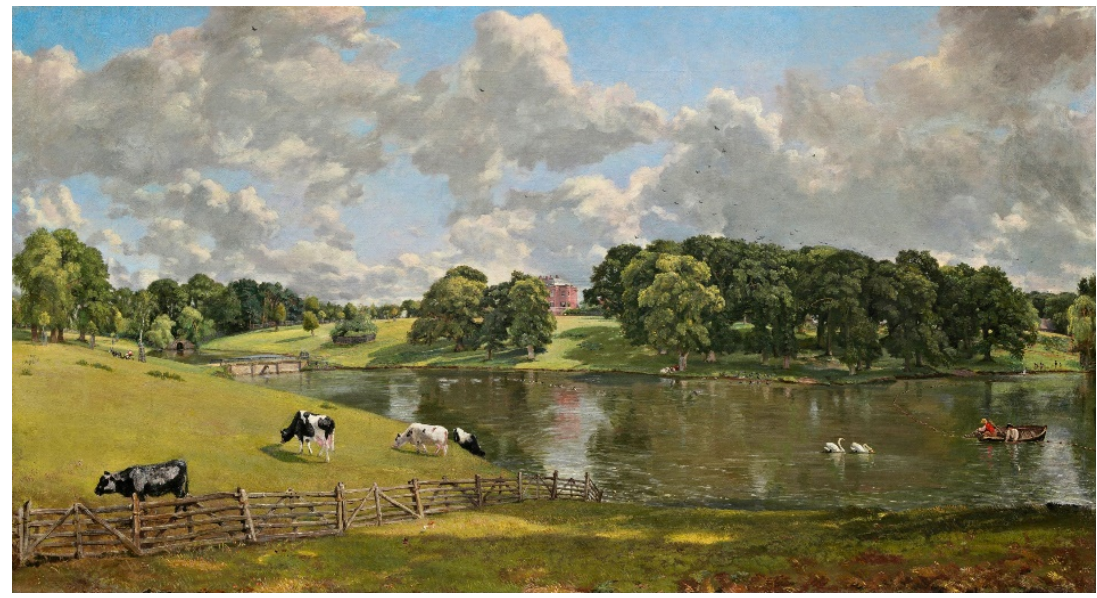

Fig. 2. Integration of naturalistic parks with the surrounding landscape, Essex - "Wivenhoe Park, Essex", author: John Constable, 1816 (National Gallery of Art, http:// www.nga.gov/content/ ngaweb/Collection/highlights/highlight1147.html)

Rys. 2. Parki naturalistyczne płynnie integrowały się z otaczającym krajobrazem, który jednocześnie przenikał do ich wnętrz, hrabstwo Essex - „Park Wivenhoe w Essex”, autor: John Constable, 1816 (National Gallery of Art, http://www.nga.gov/content/ ngaweb/Collection/highlights/high light1147.html)

Introducing of the midfields woodlots in the landscape manner as the trend of ornamenting the English landscape was also of a practical importance to agriculture, affecting an increase in yields, improvement of the climatic conditions and limiting wind erosion.

Woodlots (e.g. poplar) provided people with construction (timber) and fuel wood, as well as feed in the summer, the so-called leaf-feed (young branches along with leaves) for farm-animals, mainly sheep (Jakuszewski, 1973). As early as the beginning of the $19^{\text {th }}$ century, in various European countries, numerous societies and unions focusing on the idea of ornamenting the landscape, and aiming at developing the agriculture, were involved in popularising an introduction of such woodlots. The economic and aesthetic issues relating to woodlots in the agricultural landscape were both commented and described in the adequate literature in Poland as early as the end of the $18^{\text {th }}$ and the beginning of the $19^{\text {th }}$ century ${ }^{9}$. Less than 40 years later general Dezydery Chłapowski introduced protection plantings as a sequence of model shelterbelts, basing on the English originals, in his estate Turew, situated close to Poznań (Białobok, 1958; Jakuszewski, 1973; Raszeja, 2010; Siewniak and Mitkowska, 1998) ${ }^{10}$.

${ }^{9}$ E.g. P. Świtkowski (1782) "Budownictwo wieyskie" or F. X. Giżycki (1827) "O przyozdabianiu siedlisk wieyskich". Dezydery Chłapowski in a work entitled "O rolnictwie" (1843) presented the desirability of the establishment, structure and influence of shelterbelts on agricultural production (Jakuszewski, 1973; Siewniak and Mitkowska, 1998).

${ }^{10}$ Ecological impact on the landscape, as well as the influence of the shelterbelts in Turew on some factors of the local climate, have been investigated for many years at the shelterbelts station belonging to the Polish Academy of Sciences (PAN) operating there. 
Fortuna-Antoszkiewicz, B., Łukaszkiewicz, J. (2016). Genesis and characteristics of woodlot forms in the landscape of southern England. Nauka Przyr. Technol., 10, 4, \#50. DOI: http://dx.doi.org/10.17306/J.NPT.2016.4.50

\section{Woodlots in the Great Britain}

Trees and forest areas in the Great Britain are subject to forming and protection via regulations introduced at the governmental level. The superior document is e.g. England's trees, woods and forests - delivery plan 2008-2012 (England's trees..., without date), as well as decree Government forestry and woodlands policy statement (Government..., 2013). Then the forestry standards contain general criteria for sustainable management of afforested areas and all forests in the Great Britain. Their completion is in the form of detailed instructions in the context of other areas of interior policy, e.g.: landscape, biodiversity, soil and water protection, climatic changes and others.

Then, the subject responsible for the legislation concerning trees is the Department for Environment, Food and Rural Affairs (DEFRA), and numerous co-operating agencies and subjects, acting at DEFRA as executive agencies ${ }^{11}$, e.g.: UK Forestry Commission, Rural Payment Agency (RPA), or co-operating with DEFRA Natural England $(\mathrm{NE})^{12}$ organisation providing both scientific and practical support for nature and landscape protection in England.

\section{Forms of tree protection}

Trees and forests subject to protection are treated in the Great Britain as the good inviolable, which cannot be harmed. One of superior forms of tree protection is awarding the status of veteran trees, which owing to their age, parameters and forms (e.g. traditionally pollarded trees, etc.) possess both cultural and historical value. The trees of this type occur in higher numbers especially in historical parks and park landscapes, on the areas of old estates and in a part of the royal forests. Many of them possess marked GPS co-ordinates. The old trees are taken care of by organisations, e.g.: The veteran tree initiative, Treefest and others. Ancient woodlands are a form of areal protection. The criterion is met in the Great Britain only by the forest areas, which have been existing uninterruptedly at least since the beginning of the $17^{\text {th }}$ century.

Local councils in the Great Britain have at their disposal a number of possibilities of tree protection in a given area (e.g. districts of counties, national parks and others). One of the instruments are tree preservation orders (TPO), which are established to protect single trees of a given species, groups and afforested areas and forests from their degradation and destruction. TPO's facilitate the local planning authorities (LPA) - in keeping control over the felling procedures despite the fact that the process is carried out by the UK Forestry Commission. According to the needs TPO may be implemented very quickly (e.g. suggestion of local communities) for a period of up to 6 months, which can next be prolonged if LPA find it justified (Protected trees..., 2012).

${ }^{11}$ Executive agency is a section of a given ministry, but it utilizes separate budget means, and is independently managed to realize a part of selected executive functions of the British government (e.g. RPA). In the UK independent (non-ministerial) government departments (e.g. Forestry Commission) supervise the cases, for which the direct political supervision is declared redundant or inadequate.

${ }^{12}$ Executive non-ministerial agencies (independent public subjects), e.g. Natural England, created to carry out the realization of a defined social service in co-operation with a given department. 
Fortuna-Antoszkiewicz, B., Łukaszkiewicz, J. (2016). Genesis and characteristics of woodlot forms in the landscape of southern England. Nauka Przyr. Technol., 10, 4, \#50. DOI: http://dx.doi.org/10.17306/J.NPT.2016.4.50

\section{Subsidies for agriculture as an instrument of midfield woodlots and forest protection}

The existing system of agricultural subsidies, supervised by DEFRA and RPA, is a significant instrument of tree protection in the agricultural landscape of the Great Britain. Obtaining agricultural activity subsidies by a beneficiary in the Great Britain similarly to the situation in Poland (Lebiecka, 2007) - is based on the principle of the environmental cross-compliance.

It denotes an inter-relation between the obtained direct subsidies with meeting, by the beneficiaries, Good Agricultural and Environmental Conditions (GAEC), as well as, e.g., the Statutory Management Requirements (SMR) which are a completion of GAEC e.g. in the area of environmental protection (England's trees..., without date). GAEC comprise, among others, the principles of: managing of grasslands, keeping cleanliness and farm maintenance, soil and natural habitats protection - including trees and hedges and others. GAEC 7c section contains main acting lines concerning the way agricultural area trees should be treated by an applicant for subsidies. The one, who wishes to obtain them, is obliged to perform all the felling and tree works on his area only by permission of UK Forestry Commission. The beneficiary should also comply to the local TPO (if introduced on a given area), as well as, indicated in GAEC 7c, felling dates and cultivation measures, e.g. felling is not allowed between the $1^{\text {st }}$ of March and $31^{\text {st }}$ of August. Then, section GAEC 7a relates to the hedge maintenance on farms (including trimming dates, interplanting etc.) (DEFRA, without date). The beneficiaries who do not comply (even unintentionally) with the GAEC and SMR requirements - including the tree protection procedures in force on their area - after they have received the subsidies, may be prosecuted by limitation or withdrawal of the subsidies. RPA conducts controls of the area and farms' documentation, to verify whether principles of the environmental cross-compliance are respected. Owing to the fact that the principles of financing of agriculture in GB are complicated, the government provides the applicants with indispensable informative materials, including guides devoted to management and trees and woodlands preservation (Government Forestry..., 2013). They are supportive in learning which GAEC requirements must be complied with in respect to trees and forests growing on the area of a given estate (Protected trees..., 2012).

\section{Tree felling procedures}

The British tree felling control is a very significant aspect of trees' protection. Felling licenses are issued by the UK Forestry Commission basing on defined conditions (e.g. proprietary, temporary, spatial, natural etc.). Issuing permission and defining its range depends upon the assignment of a given area e.g. the present forms of natural preservation and culture etc. The UK Forestry Commission considers an application in respect of the impact the suggested changes might have on the environment via e.g. the level of the effect of the investment (below and above the ground) on the locally growing trees and present woodlands (BS 5837:2012, 2012). Both local authorities and organisations can be asked for consulting the problem of the planned tree felling. The 
Fortuna-Antoszkiewicz, B., Łukaszkiewicz, J. (2016). Genesis and characteristics of woodlot forms in the landscape of southern England. Nauka Przyr. Technol., 10, 4, \#50. DOI: http://dx.doi.org/10.17306/J.NPT.2016.4.50

basic condition to obtain the license is, among others, carrying out new plantings (natural compensation) and their maintenance for 10 years or restoration of woodlots situated in a different place than the investment itself (BS 5837:2012, 2012). In English documents (similarly to the Polish ones) concerning felling licenses there are exemptions defining when natural compensation is not obligatory (Felling licences..., without date).

\section{Results - woodlots as an element of southern England landscape physiognomy}

The observations carried out in April 2015 on the midfield woodlots of southern England showed that they occur in a sequence of spatial structures which are analogical to those met in English parks and gardens. Below are some selected examples (classic classification acc. to Hejmanowski et al., 1964):

- single form - single trees or shrubs (soliters), sparsely distributed among fields, meadows, and grasslands (Fig. 3a) or in park interiors (Fig. 3b) ${ }^{13}$;

- group form - plantings of trees and shrubs in small clusters of any shape; they take an area of up to 10 ares, and consist of a few up to a dozen or so trees or shrubs (Figs. 4a, 4b) ${ }^{14}$;

- single-row form - one-row plantings of trees or trees and shrubs; midfield and waterside woodlots may have one- or two-sided form (Fig. 5a); in parks - most frequently as a regular arrangement ${ }^{15}$ (Fig. 5b);

- belt form - linear arrangement of trees and shrubs groups in multi-rows or arranged irregularly; the tree belt not wider than $10.0 \mathrm{~m}$ (Figs. 6a, 6b);

- row and belt form - constructed exclusively of shrub plants is a hedge; it can be distinguished: low hedges (height up to $1.0 \mathrm{~m}$ ), medium (height 1.0-3.0 m), and high (height above $3.0 \mathrm{~m}$ ); they can be independent spatial elements (e.g. field borderlines or along roads) or combined with trees e.g. in a row woodlot (Hejmanowski et al., 1964; Szymanowski, 1967) (Figs. 7a, 7b);

- surface form - trees and shrubs plantings on areas larger than 10 ares - can be found among fields (Fig. 8a), as well as in parks (Fig. 8b).

${ }^{13}$ Soliters - individual tree or shrub forms growing within a limited area - landscape interior (Fortuna-Antoszkiewicz, 2012). They are usually dendrological valuable specimens (precious local or foreign species or their rare varieties) with high aesthetic qualities (attractive habit, decorative value of the organs: shoots, leaves, flowers) (Majdecki, 1981; Siewniak, 1990).

${ }^{14}$ Group of trees or shrubs - a few or a dozen or so trees or shrubs making up a compact compositional unity, applied as an independent element in an open space - the landscape interior (Fortuna-Antoszkiewicz, 2012; Majdecki, 1993b; Siewniak and Mitkowska, 1998). It can be found in various forms e.g.: free form (irregular), regular form, compact group, sparse group.

${ }^{15}$ Espalier - it is a regular, most frequently one-row tree planting, which crowns make up compact walls more than $220 \mathrm{~cm}$ high (Fortuna-Antoszkiewicz, 2012; Majdecki, 1993b; Siewniak and Mitkowska, 1998). The effect is obtained as a result of applying adequate branch cutting or using trees having natural geometric forms (Siewniak, 1990). In garden plans the formed espaliers were used to construct geometrized garden interiors (e.g. garden salons, cabinets, mazes, hippodromes), emphasizing the depth of the spatial perspective composition (coulisses arrangements) (Siewniak and Mitkowska, 1998), framing of main roads and important prospects (Majdecki, 1993b). 
Fortuna-Antoszkiewicz, B., Łukaszkiewicz, J. (2016). Genesis and characteristics of woodlot forms in the landscape of southern England. Nauka Przyr. Technol., 10, 4, \#50. DOI: http://dx.doi.org/10.17306/J.NPT.2016.4.50

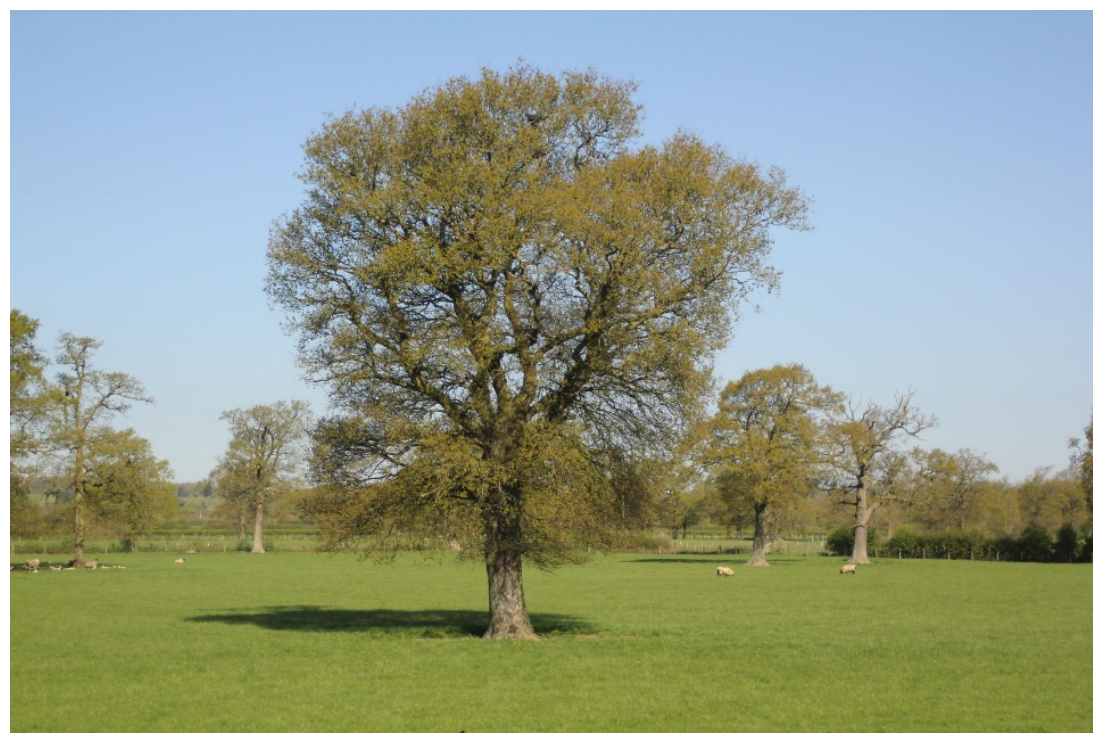

Fig. 3a. Single tree in the middle of a grassland - Surrey

Rys. 3a. Sródpolne pojedyncze drzewo w krajobrazie pastwisk - hrabstwo Surrey

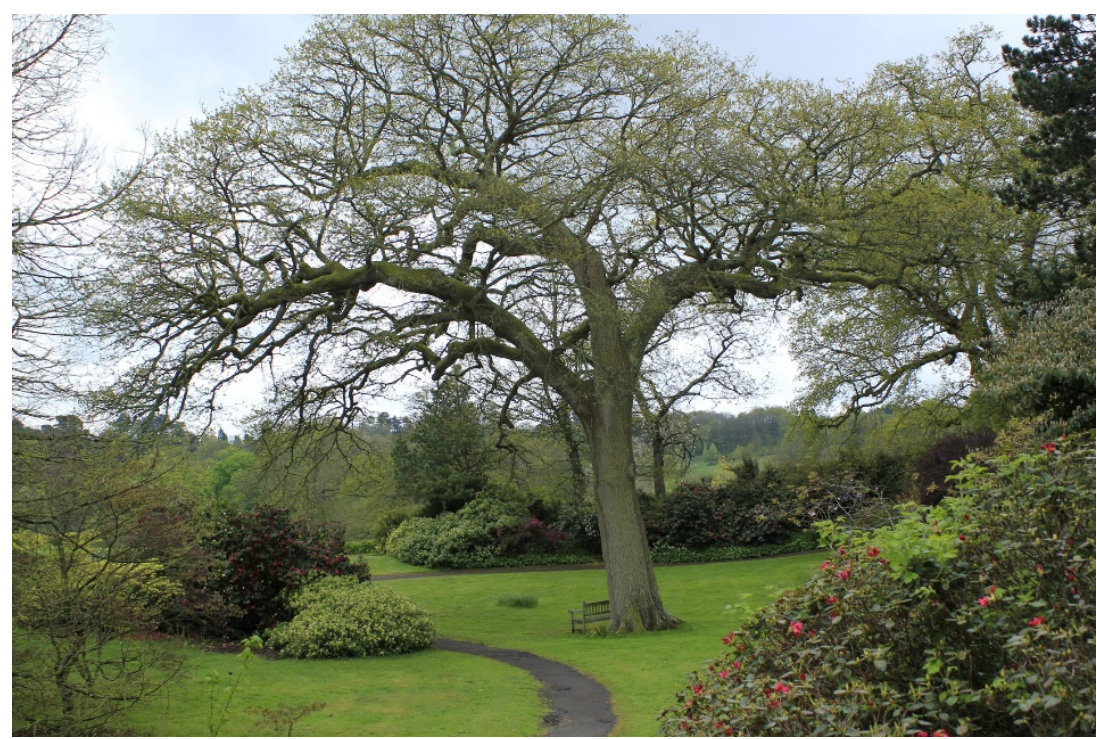

Fig. 3b. Single tree (soliter) in the park's interior - Borde Hill Garden Rys. 3b. Pojedyncze drzewo (soliter) we wnętrzu parkowym - Ogród w Borde Hill 
Fortuna-Antoszkiewicz, B., Łukaszkiewicz, J. (2016). Genesis and characteristics of woodlot forms in the landscape of southern England. Nauka Przyr. Technol., 10, 4, \#50. DOI: http://dx.doi.org/10.17306/J.NPT.2016.4.50

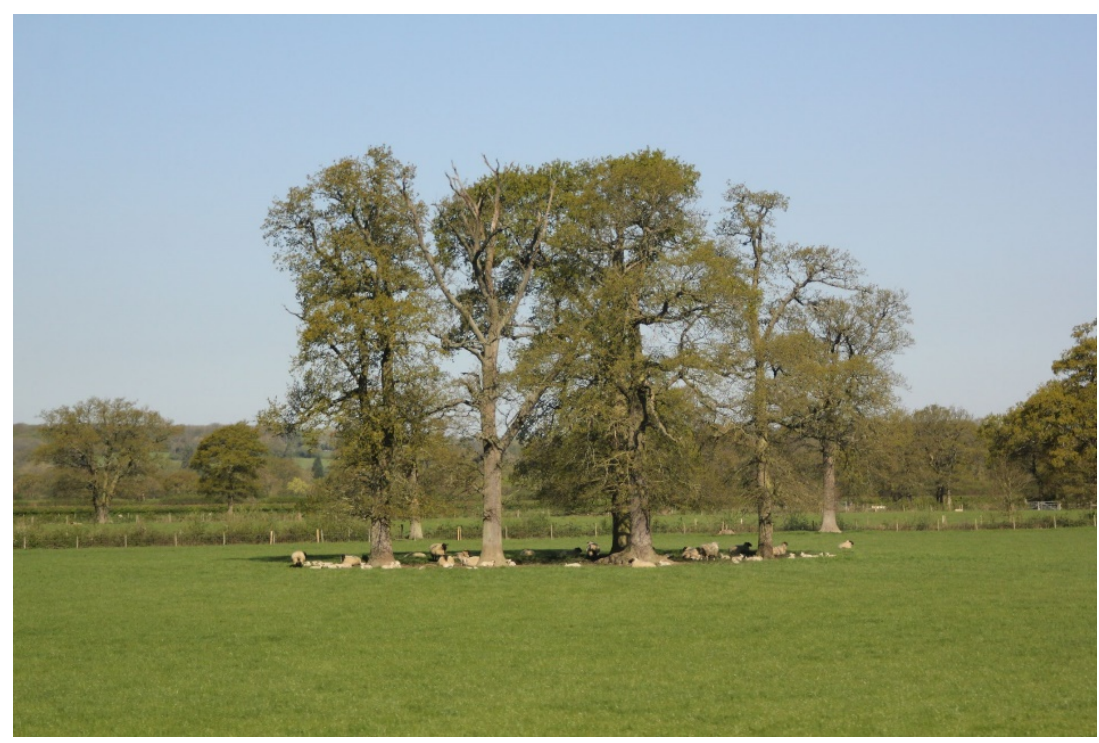

Fig. 4a. Group of trees in the middle of a grassland - Surrey Rys. 4a. Śódpolna grupa drzew - hrabstwo Surrey

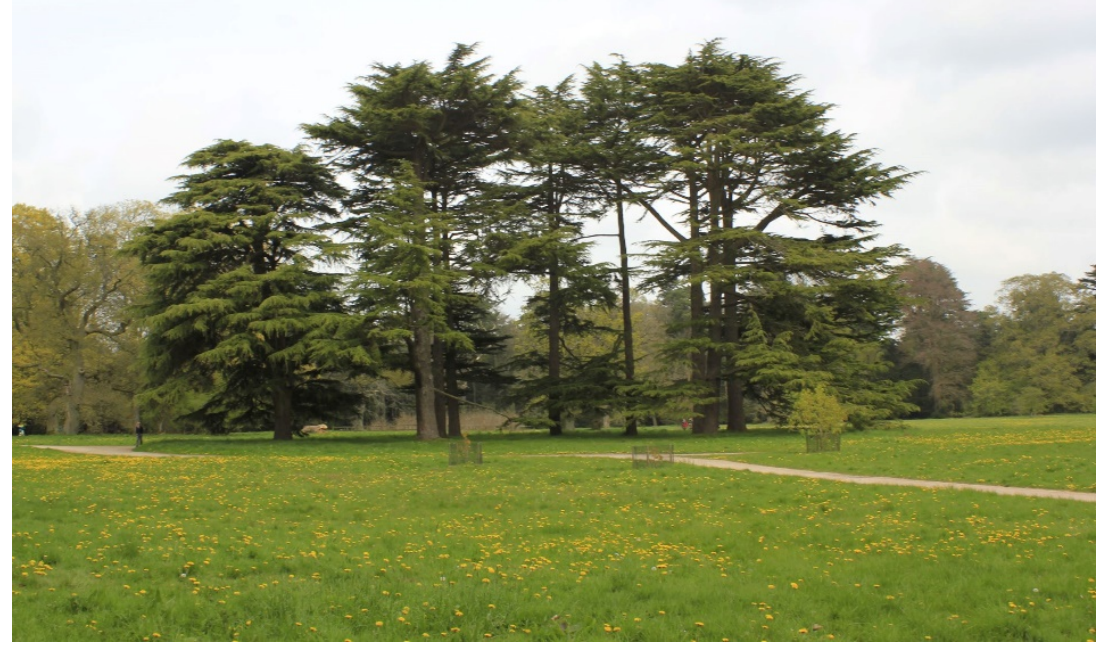

Fig. 4b. Monospecific group of coniferous trees (cedars) in the park's interior - Westonbirt Arboretum

Rys. 4b. Grupa drzew iglastych (cedry) we wnętrzu parkowym - Westonbirt Arboretum 
Fortuna-Antoszkiewicz, B., Łukaszkiewicz, J. (2016). Genesis and characteristics of woodlot forms in the landscape of southern England. Nauka Przyr. Technol., 10, 4, \#50. DOI: http://dx.doi.org/10.17306/J.NPT.2016.4.50

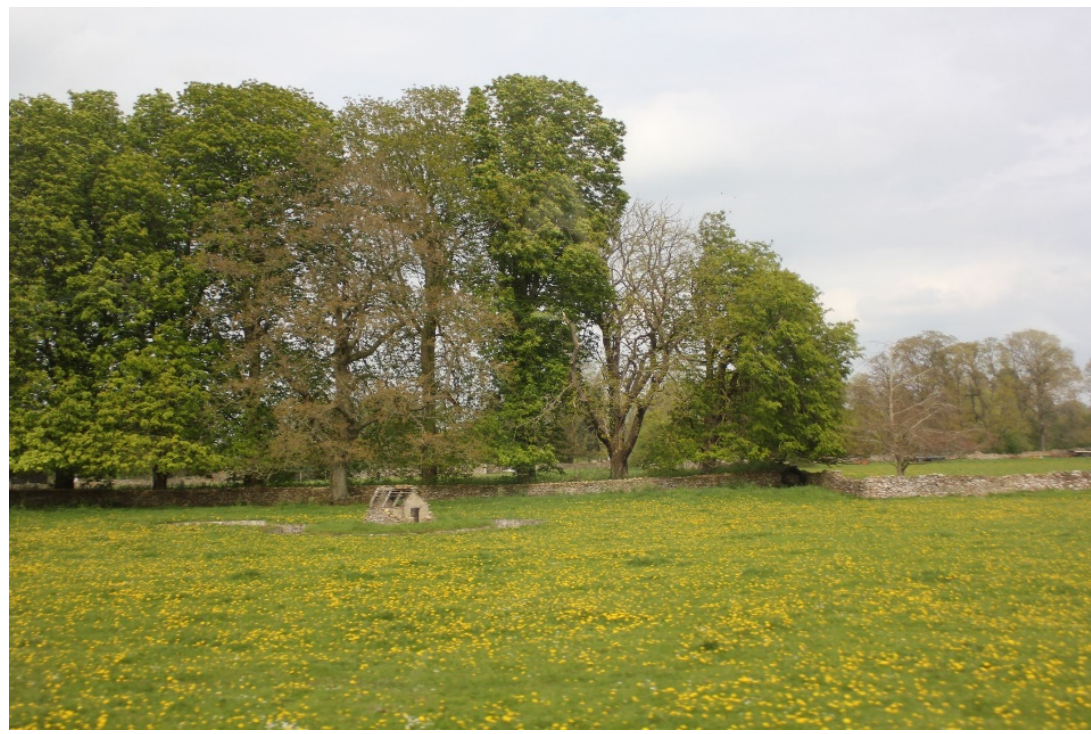

Fig. 5a. Row of trees along the border of pastures and crop fields - Surrey Rys. 5a. Rząd drzew na granicy pól i pastwisk - hrabstwo Surrey

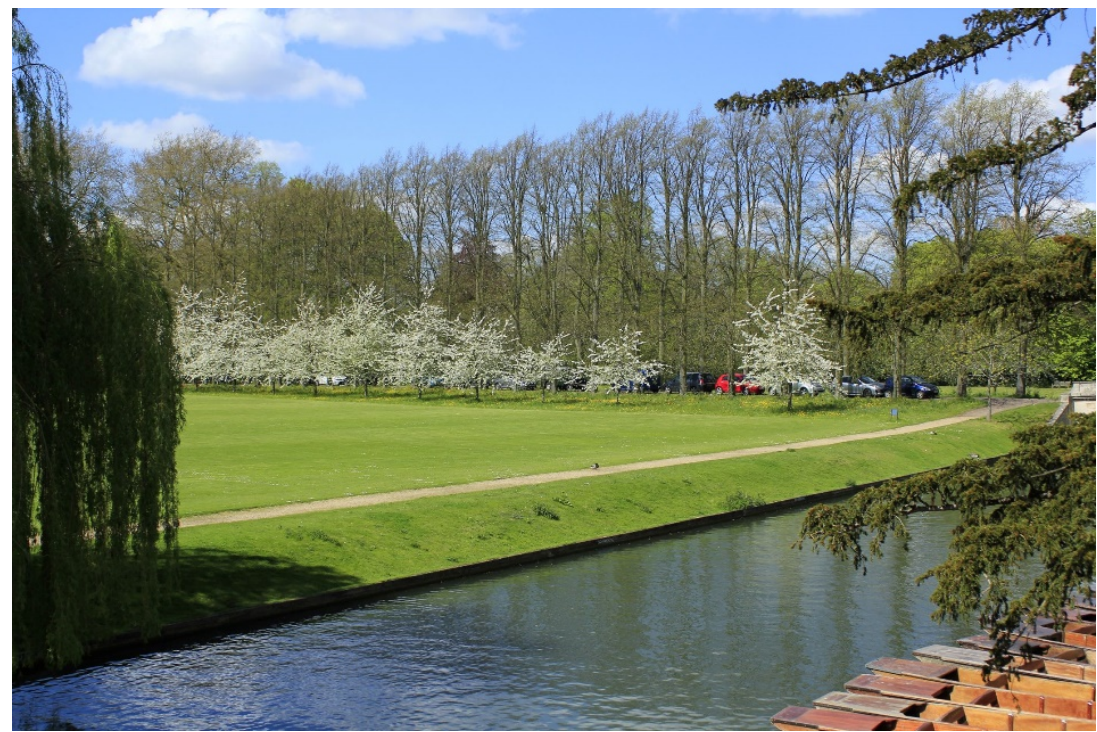

Fig. 5b. Double row of cherry trees and poplars along the park's interior - Cambridge Rys. 5b. Szpaler wiśni i topól na granicy wnętrza parkowego - Cambridge 
Fortuna-Antoszkiewicz, B., Łukaszkiewicz, J. (2016). Genesis and characteristics of woodlot forms in the landscape of southern England. Nauka Przyr. Technol., 10, 4, \#50. DOI: http://dx.doi.org/10.17306/J.NPT.2016.4.50

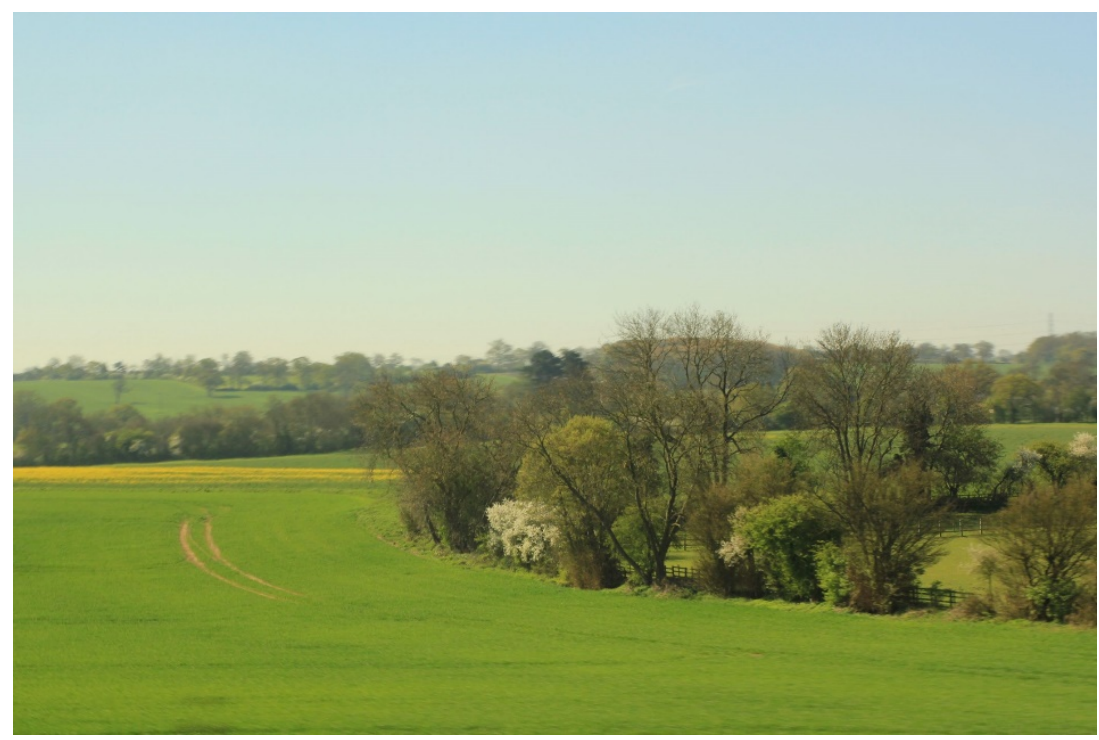

Fig. 6a. Belt of trees and shrubs along the border of pastures and crop fields - Surrey Rys. 6a. Pas drzew i krzewów na granicy pól i pastwisk - hrabstwo Surrey

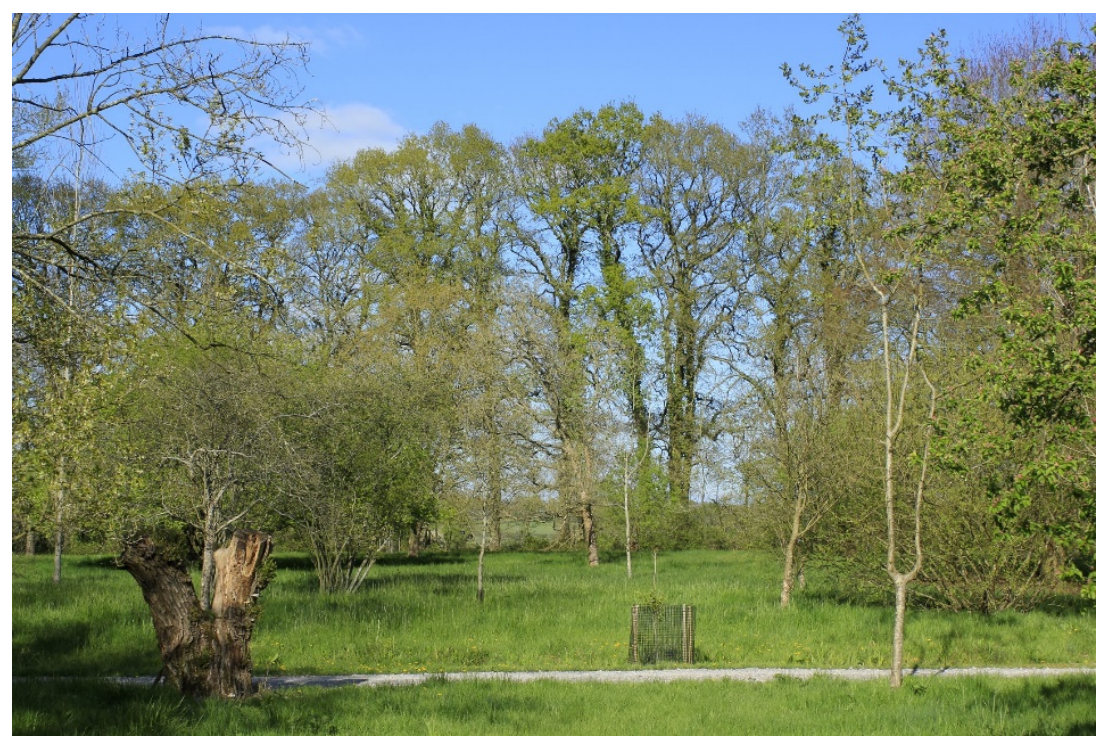

Fig. 6b. Belt of trees and shrubs on the parkland border - Hillier Arboretum Rys. 6b. Pas drzew i krzewów na granicy parku - Hillier Arboretum 
Fortuna-Antoszkiewicz, B., Łukaszkiewicz, J. (2016). Genesis and characteristics of woodlot forms in the landscape of southern England. Nauka Przyr. Technol., 10, 4, \#50. DOI: http://dx.doi.org/10.17306/J.NPT.2016.4.50

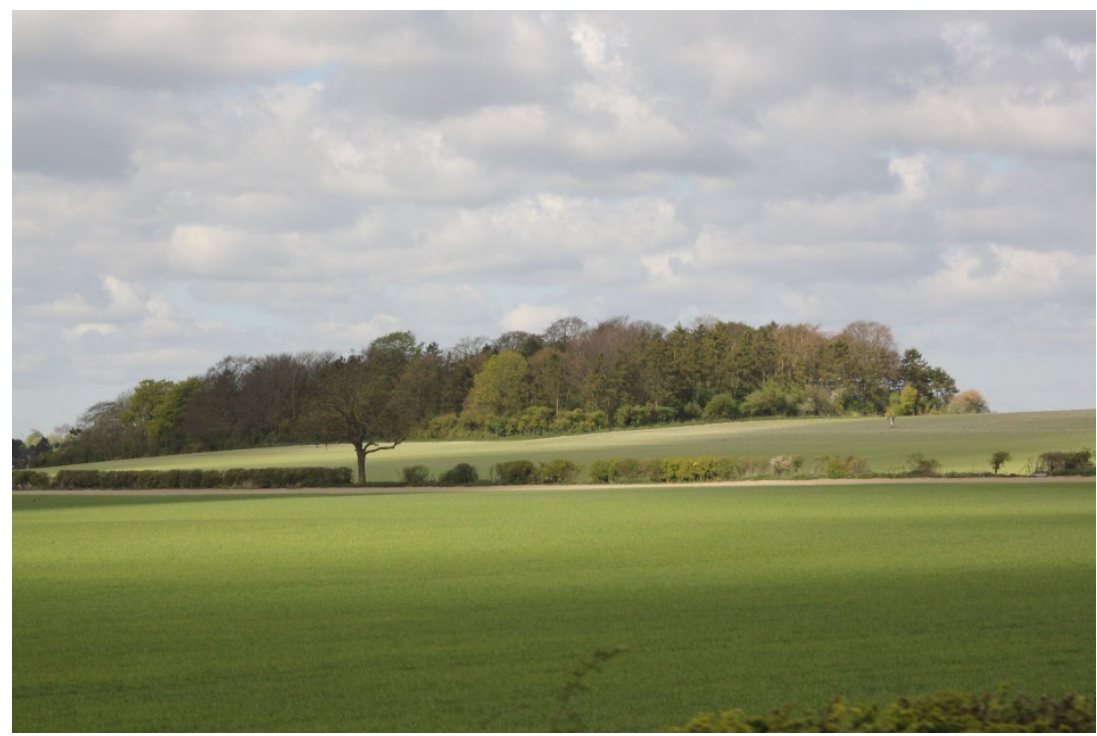

Fig. 7a. Groves and thickets among fields - Surrey

Rys. 7a. Śródpolne gaje i zagajniki - hrabstwo Surrey

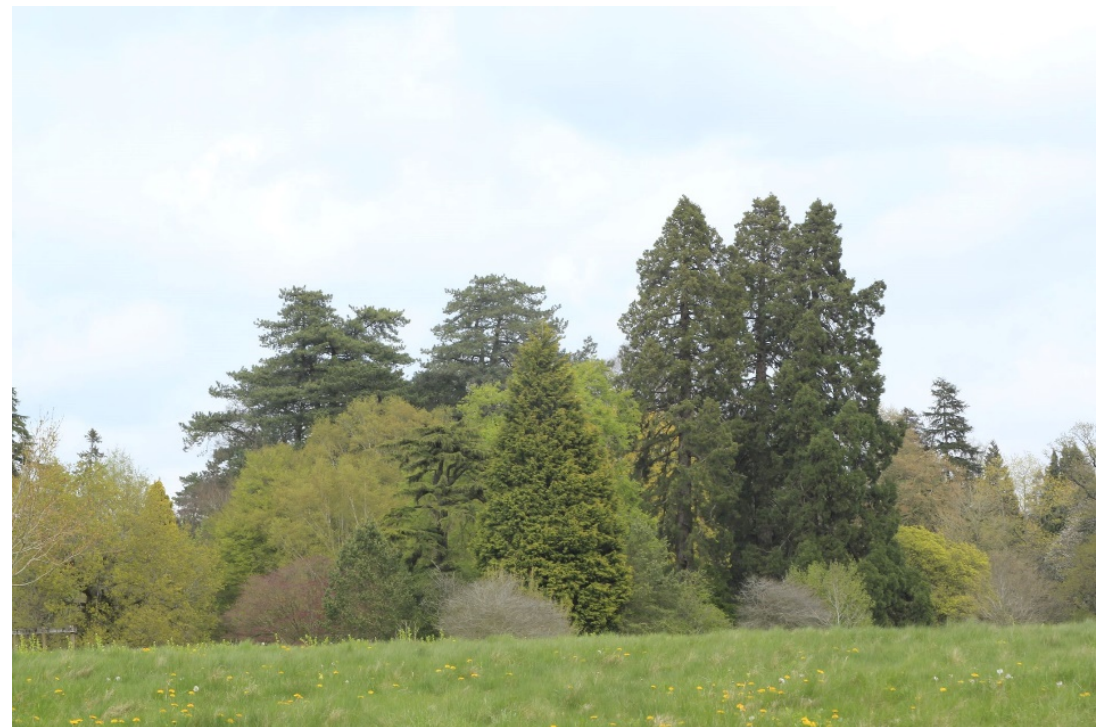

Fig. 7b. Tree massif in the park - Westonbirt Arboretum

Rys. 7b. Masyw drzew w parku - Westonbirt Arboretum 
Fortuna-Antoszkiewicz, B., Łukaszkiewicz, J. (2016). Genesis and characteristics of woodlot forms in the landscape of southern England. Nauka Przyr. Technol., 10, 4, \#50. DOI: http://dx.doi.org/10.17306/J.NPT.2016.4.50

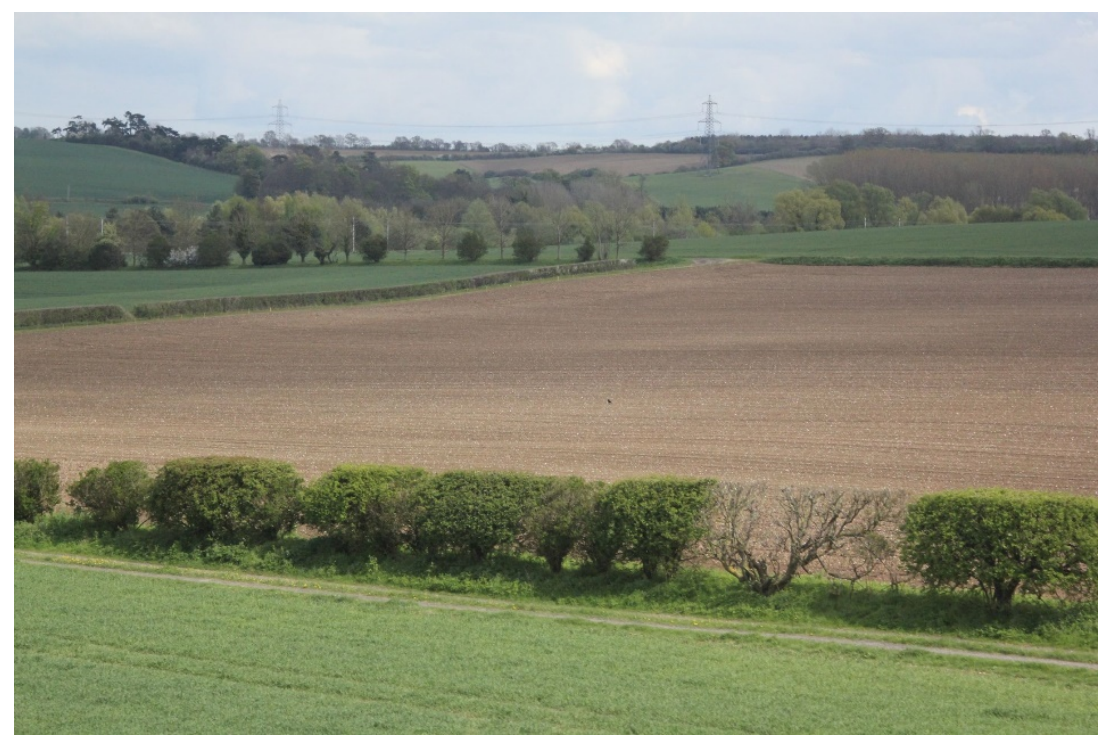

Fig. 8a. Hedges along fields' borders - Surrey

Rys. 8a. Żywopłoty śródpolne - hrabstwo Surrey

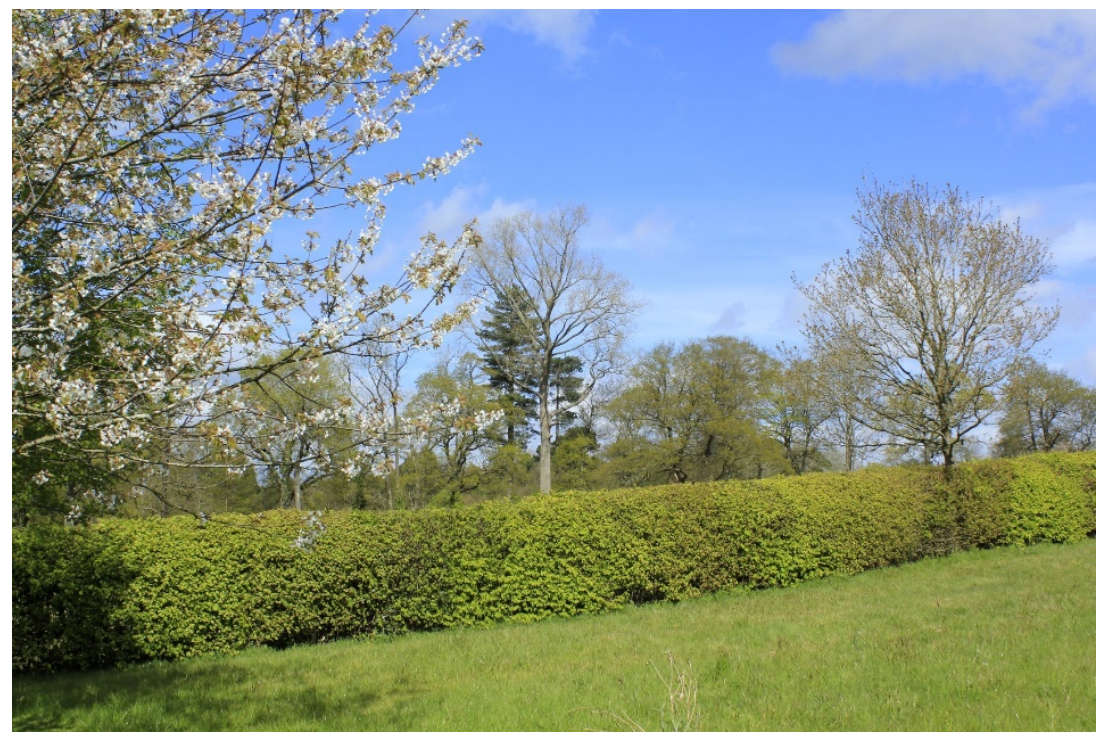

Fig. 8b. Hedge in the park - Royal Botanic Gardens, Wakehurst

Rys. 8b. Żywopłot parkowy - Królewskie Ogrody Botaniczne, Wakehurst 
Fortuna-Antoszkiewicz, B., Łukaszkiewicz, J. (2016). Genesis and characteristics of woodlot forms in the landscape of southern England. Nauka Przyr. Technol., 10, 4, \#50. DOI: http://dx.doi.org/10.17306/J.NPT.2016.4.50

Woodlots are characterized by variable structure, as far as their spatial arrangement (in vertical and horizontal arrangement), as well as species selection (Hejmanowski et al., 1964) are concerned, which has a significant impact on their form shape. Spatial construction is defined by layered structure and horizontal arrangement (manner of mixing successive species). The following are distinguished in the vertical arrangement: one-layer woodlots - the trees found here show insignificant height differentiation, and the crowns are set at a similar level; two-layer woodlots - the trees form clear levels of various heights, at the same time the lower layer treetops penetrate the upper layer to a small degree; multi-layer woodlots - having wooded vegetation on high, medium and low levels, where the tree crowns penetrate one another. The horizontal level denotes spacing between the individual plants of the woodlots; it can be either regular or irregular (the spacing refers to one-row woodlots).

In respect of the species composition there can be one-species arrangements (monoculture ones) or multi-species ones (composition of various, at least two tree and shrub species). In multi-species arrangements the individual species may take a different manner of mixing: singular - the species are mixed individually and do not create groups; the singular mixing may take both regular and irregular character; group mixing of one-species group, a few specimens of one species, having an area of up to 2.0 ares; cluster - mixing of one-species clumps of any shape, having an area of 2.0 10.0 ares; row - species are planted in rows; uneven - fully irregular mixing.

\section{Summary and conclusions}

The woodlots found in the English landscape have been shaped following the models coming from the field of philosophy, poetry and painting. With the course of time, they have become one of the most characteristic components of the England's landscape having an outstanding cultural value.

Analysing specimens of midfield-woodlots in the southern part of England it can be observed that they have been subject to a specific cultivation within the frame of the traditional agricultural landscape ${ }^{16}$. It is being realised via forming, maintenance and preservation of the cultural landscape, parallel with respecting the cultural, ecological and economical aspects. A general conclusion deriving from the carried out studies is a statement saying that the forms of woodlots encountered in the agricultural landscape and English parks are practically the same. Both in the open landscape and parks classical spatial forms i.e.: soliters (single trees), groups, clusters (groves, thickets and massifs), are observed along with linear forms (rows, belts, both formed and non-formed hedges).

The described way of forming woodlots makes the agricultural and park landscape penetrate each other creating multi-scale landscape composition (an original idea introduced by the British into the garden-art in the $18^{\text {th }} \mathrm{c}$.). A significant part of the composition are vast panoramas and distant views, which are strictly kept in England till the present times. Looking at the contemporary English cultural landscape and comparing it

${ }^{16}$ The term "landscape cultivation" is used in analogy to the term applied by Prof. Wodziczko (Białobok, 1958; Siewniak and Mitkowska, 1998). 
Fortuna-Antoszkiewicz, B., Łukaszkiewicz, J. (2016). Genesis and characteristics of woodlot forms in the landscape of southern England. Nauka Przyr. Technol., 10, 4, \#50. DOI: http://dx.doi.org/10.17306/J.NPT.2016.4.50

with the one recorded by the landscape painting over 200 years ago, it is easily noticeable that woodlots have always been its indispensable part. The example of England can be presented as a phenomenon of factual preservation and conservation of a historical cultural landscape which presently viewed on old paintings, after two centuries still presents the same virtually unchanged shape. Conscious woodlots forming, as well as their competent cultivation and intervention directed at every tree - to the indispensable minimum - determine the high tree cultivation culture in England.

The English manner of treating the landscape on a large scale, with a protection of individual natural components, as well as whole landscape sequences, shows as a kind of a model for forming and protecting the cultural landscape in Poland. It used to be like that in the past and it is worth of reminding today. It seems to be vital at the moment when a far-advanced degradation of the traditional Polish landscape is observed (spatial chaos), including the progressing destruction of historical midfield, alley and park woodlots which frequently results from improper cultivation, and in reality devastation of trees.

\section{References}

Białobok, S. (1958). Rola zadrzewień przydrożnych w uprawie krajobrazu. Ogród Park Krajobr., $2,2,35-36$.

BS 5837:2012. (2012). Trees in relation to design, demolition and construction. Recommendations. BSI. http://shop.bsigroup.com/en/ProductDetail/?pid=000000000030213642 [access: 14.06.2015].

DEFRA. https://www.gov.uk/government/organisations/department-for-environment-food-ruralaffairs/ [access: 12.06.2015].

Delivery forestry policy. England: Forestry Commission. http://www.forestry.gov.uk/forestry/infd7t9b67/ [access: 17.06.2015].

England's trees, woods and forests - delivery plan 2008-2012. England: Forestry Commission. http://www.forestry.gov.uk/pdf/eng-etwf-delivery-plan.pdf/\$FILE/eng-etwf-delivery-plan.pdf/ [access: 08.06.2015].

Felling licences exemptions. England: Forestry Commission. http://www.forestry.gov.uk/forestry/ infd-6dfkw6/ [access: 11.06.2015].

Fortuna-Antoszkiewicz, B. (2012). Przemiany formy elementów i układów ogrodowych wzdłuż traktów komunikacyjnych na przykładzie Traktu Królewskiego w Warszawie. Monogr. Szt. Ogrodu Szt. Krajobr., 2.

Government Forestry and Woodlands Policy Statement. (2013). England: Forestry Commission, Department for Environment, Food \& Rural Affairs. https://www.gov.uk/government/uploads/ system/uploads/attachment_data/file/221023/pb13871-forestry-policy-statement.pdf/ [access: 11.06.2015].

Guidance. Ancient woodland and veteran trees: protecting them from development. (2014). England: Forestry Commission. https://www.gov.uk/ancient-woodland-and-veteran-trees-protec tion-surveys-licences/ [access: 13.06.2015].

Guidance. Trees and woodland: management and conservation. (2013). England: Department for Environment, Food \& Rural Affairs. https://www.gov.uk/trees-and-woodland-managementand-conservation/ [access: 13.06.2015].

Hejmanowski, S., Milewski, J., Terpiński, Z. (1964). Poradnik zadrzewieniowca. Warszawa: PWRiL. 
Fortuna-Antoszkiewicz, B., Łukaszkiewicz, J. (2016). Genesis and characteristics of woodlot forms in the landscape of southern England. Nauka Przyr. Technol., 10, 4, \#50. DOI: http://dx.doi.org/10.17306/J.NPT.2016.4.50

Jakuszewski, T. (1973). Uprawa topoli w Polsce. In: S. Białobok (ed.), Topole (Populus L.). Nasze Drzewa Leśn. Monogr. Popularnonauk., 12, 463-464.

Lebiecka, K. (2007). Wyniki produkcyjne i ekonomiczne gospodarstw prowadzących produkcję rolniczą w różnych warunkach przyrodniczych. Zesz. Nauk. SGGW Probl. Roln. Świat., 17, 2, 2, 381-388.

Majdecki, L. (1981). Historia ogrodów. Warszawa: PWN.

Majdecki, L. (1993a). Metoda ochrony wartości przyrodniczo-kulturowych Skarpy Warszawskiej. In: B. Wierzbicka (ed.), Skarpa Warszawska. Biblioteka Towarzystwa Opieki nad Zabytkami (pp. 135-146). Warszawa: Towarzystwo Opieki nad Zabytkami.

Majdecki, L. (1993b). Ochrona i konserwacja zabytkowych założeń ogrodowych. Warszawa: Wyd. Nauk. PWN.

Mayer, L. (2014). Capability Brown and the English landscape garden. UK: Shire Publ.

Protected trees. A guide to tree preservation procedures. (2012). London: Department for Communities and Local Government. https:/www.gov.uk/government/uploads/system/uploads/att achment_data/file/244528/2127793.pdf/ [access: 15.06.2015].

Raszeja, E. (2010). Struktura krajobrazu rolniczego w Parku Krajobrazowym im. gen. Dezyderego Chłapowskiego. Acta Sci. Pol. Adm. Locor., 9, 1, 97-110.

Seneta, W. (1987). Dendrologia. Warszawa: PWN.

Siewniak, M. (1990). Gospodarka drzewostanem w założeniach parkowo-ogrodowych. Kom. Dendrol., 16, 2-47.

Siewniak, M., Mitkowska, A. (1998). Tezaurus sztuki ogrodowej. Warszawa: Rytm.

Szymanowski, T. (1967). Żywopłoty. Technologia kształtowania i dobór roślinny. Warszawa: PWN.

Toomer, S. (2010). Planting and maintaining a tree collection. London: Timber Press.

\title{
GENEZA I CHARAKTERYSTYKA FORM ZADRZEWIEŃ W KRAJOBRAZIE POŁUDNIOWEJ ANGLII
}

\begin{abstract}
Streszczenie
Wstęp. Praca syntetycznie prezentuje wyniki badań nad genezą i cechami form zadrzewień w krajobrazie rolniczym Anglii. Wytworzenie tego rodzaju układów roślinnych wynikało m.in. z inspiracji Anglików popularnym w XVI i XVII wieku mitem arkadyjskim oraz z fascynacji przyrodą, będącej wynikiem podróży m.in. do Włoch czy na Daleki Wschód. W konsekwencji na przełomie XVII i XVIII wieku wytworzył się w Anglii bardzo specyficzny rodzaj krajobrazu kulturowego, którego pastersko-rolniczy charakter znalazł pewne odwzorowanie w archetypie XIX-wiecznego parku angielskiego. Widać to szczególnie dobrze na przykładzie zadrzewien, których niezwykle podobne formy występują zarówno w angielskim krajobrazie rolniczym, jak i w angielskich parkach. Celem badań było generalne przedstawienie form i funkcji wybranych przykładów zadrzewień występujących na terenie południowej Anglii.

Material i metody. Dane gromadzono w kwietniu 2015 roku podczas warsztatów naukowych Polskiego Towarzystwa Dendrologicznego poświęconych roślinom drzewiastym południowej Anglii (m.in. hrabstwa Surrey i okolic). Autorzy analizowali in situ fizjonomię krajobrazu z ukształtowanym kompleksowo systemem zadrzewień śródpolnych oraz wykonali dokumentację fotograficzną.

Wyniki i wnioski. Charakterystyczna maniera kształtowania form zadrzewień w krajobrazie pastersko-rolniczym Anglii jest niemalże analogiczna do istniejącej w angielskich parkach naturalistycznych XIX wieku. Jednocześnie zadrzewienia są zupełnie podobne do tych przedstawianych
\end{abstract}


Fortuna-Antoszkiewicz, B., Łukaszkiewicz, J. (2016). Genesis and characteristics of woodlot forms in the landscape of southern England. Nauka Przyr. Technol., 10, 4, \#50. DOI: http://dx.doi.org/10.17306/J.NPT.2016.4.50

w XIX-wiecznym malarstwie pejzażowym. Jest to swoisty fenomen tak skutecznej ochrony fizjonomii krajobrazu kulturowego, który zachował praktycznie niezmieniony wygląd mimo upływu ponad dwóch stuleci. Ukazanie wyjątkowego dla tradycyjnego krajobrazu rolniczego i parkowego południowej Anglii znaczenia i wartości zadrzewień może stanowić wzorzec kształtowania i ochrony krajobrazu kulturowego w Polsce - zarówno w przeszłości, jak i współcześnie.

Słowa kluczowe: formy zadrzewień, parki i krajobraz południowej Anglii, ochrona krajobrazu

Corresponding address - Adres do korespondencji:

Jan Lukaszkiewicz, Katedra Architektury Krajobrazu, Szkoła Główna Gospodarstwa Wiejskiego $w$ Warszawie, ul. Nowoursynowska 159, budynek 37, 02-776 Warszawa, Poland, e-mail: jan_lukaszkiewicz@sggw.pl

Accepted for publication - Zaakceptowano do opublikowania:

6.12.2016

For citation - Do cytowania:

Fortuna-Antoszkiewicz, B., Eukaszkiewicz, J. (2016). Genesis and characteristics of woodlot forms in the landscape of southern England. Nauka Przyr. Technol., 10, 4, \#50. DOI: http://dx. doi.org/10.17306/J.NPT.2016.4.50 